\title{
ОСМОРЕГУЛЯЦИЯ И ЕЁ РОЛЬ В РЕЗИСТЕНТНОСТИ КЛЕTOK DUNALIELLA SALINA ПРИ ДЕЙСТВИИ РАЗЛИЧНЫХ ДОЗ УФ-С ИЗЛУЧЕНИЯ
}

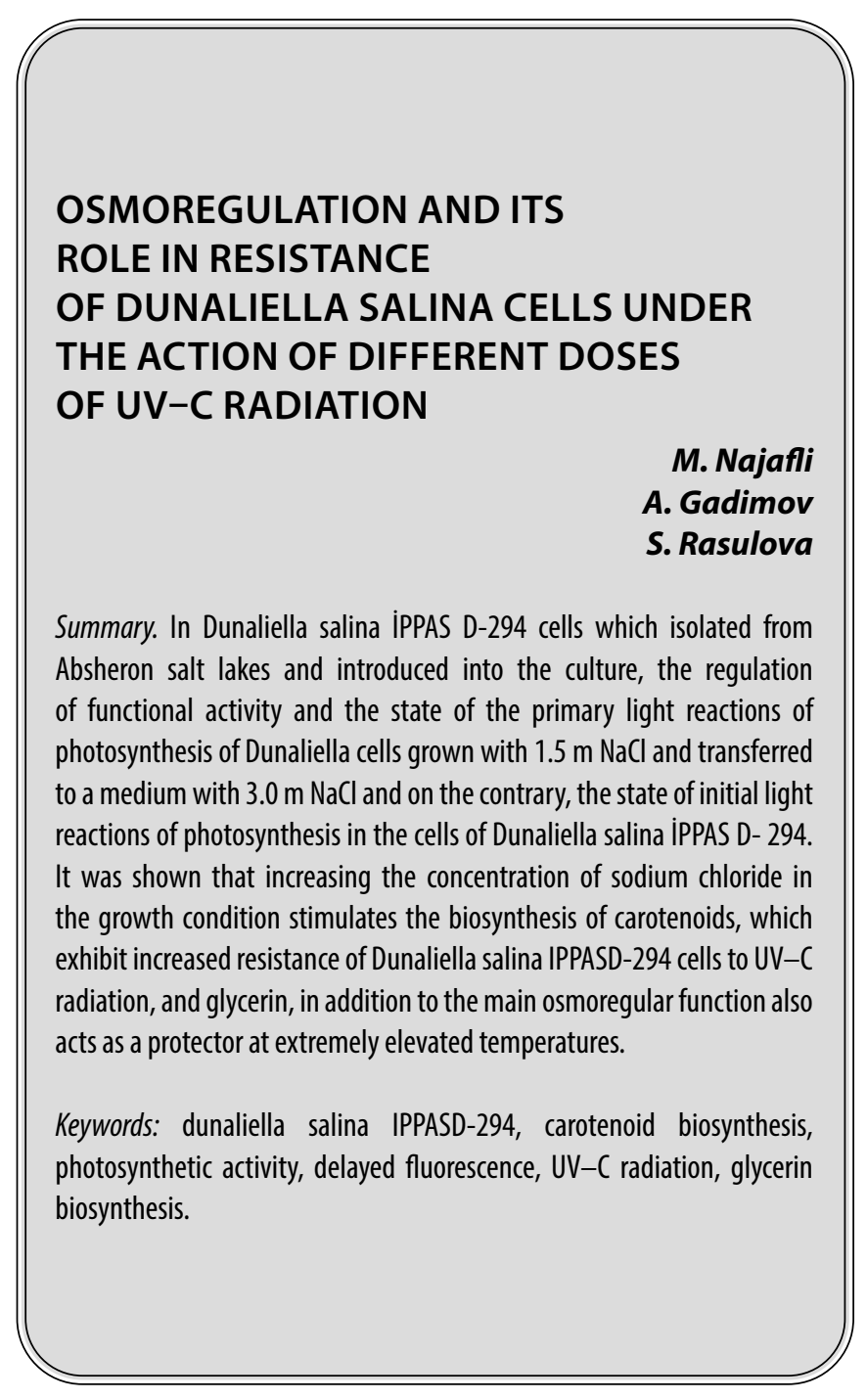

$\mathbf{0}$ писанные настоящему времени механизмы осморегуляции у водорослей можно условно разделить на два основных типа: «метаболический» связанный с синтезом и расщеплением в клетках целого ряда специфических осмотически активных органических соединений, и «ионный» осуществляемый за счет поглощения и выделения клетками тех или иных неорганических ионов [1,3,6]. Механизмы первого типа локализованы в цитоплазматических структурах, так как синтез органических осмолитов непосредственно связан с общими процессами метаболизма. Подобные осмолиты осуществляют протекторную функцию, предотвращая

\author{
Наджафли Махаббат Гумбат оглы \\ Доктор философии по биологии, дочент, Бакинский \\ Государственный Университет \\ Mohobbatnecefli@gmail.com \\ Гадимов Аладдин Гасан оглы \\ Доктор философии по биологии, доцент, Институт \\ Ботаники НАНА \\ agadimov@mail.ru \\ Расулова Садагат Мирбаба гызы \\ Доктор философии по биологии, дочент, Институт \\ Ботаники НАHA \\ Sadaqat65@mail.ru
}

Аннотация. В клетках Dunaliella salina IPPAS D- 294, выделенных из соленных озер Апшерона и введенных в культуру исследована регуляция функциональной активности, и состояние первичных световых реакций фотосинтеза клеток Dunaliella, выращенных при 1,5 м NaCl и перенесенных в среду с 3,0 м NaCl и наоборот, а также выявление устойчивости клеток к острому облучению различными дозами УФ-С света. Показано, что повышения концентрации хлористого натрия в среде выращивания, стимулируют биосинтез каротиноидов, которые проявляют повышенную резистентность клеток Dunaliella salina IPPASD-294 к УФ-С излучению, а глицерин кроме основной осморегулярной функции, выполняет также роль протектора в экстремально повышенных температурах.

Ключевые слова: dunaliella salina IPPASD-294, биосинтез каротиноидов, Фотосинтетическая активность, замедленная флуоресценция, УФ-С излучения, биосинтез глицерина. 
тину происходящих изменений, можно выделить изо всей этой цепи взаимосвязанных реакции изменения внутриклеточного осмотического давления. В принципе у каждого организма должны существовать оба типа осморегуляции и что они могут функционировать одновременно. Однако данных об относительной роли, каждого из этих типов осморегуляции в общем осморегуляторном процессе организма очень немного. К тому же в зависимости от морфологической структуры клеток функционирование одного из типов осморегуляции всегда в той или иной мере маскируется действием механизма другого типа. Поэтому функционирование механизмов «метаболического» типа исследуют, как правило, на таких водорослях, как Dunaliella, тогда как исследования механизмов "ионного" типа проводят в основном на гигантских одноклеточных водорослях типа Valonia, у которых центральная вокуолярная полость может занимать до 99\% общего объема организма. Во всех известных нам исследованиях процесс адаптации различных видов Dunaliella к изменению солености (осмотического давления) среды всегда сопровождался большим или меньшим осмотическим шоком при перенесении водорослей в иную среду [3]. В сочетании с нежелательным воздействием на клетки процессов центрифугирования и отмывки в изотоническом растворе иного состава осмотический шок приводит к торможению в течение некоторого периода процессов роста и размножения водорослей (лаг период). При этом вследствие гетерогенности популяции водорослей как по ее генетическому, так и по возрастному составу обратимое торможение процессов жизнедеятельности наблюдается не у всех клеток-часть из них погибает. Несомненно, что соотношение между числом погибших клеток и числом клеток, процессы жизнедеятельности в которых только на время заторможены, зависит как от физиологических особенностей самой культуры, так и от характера воздействия на нее при перенесении клеток в иную среду $[2,5]$.

Целью настоящей работы является исследования регуляции функциональной активности, и состояния первичных световых реакций фотосинтеза клеток Dunaliella, выращенных при 1,5 м NaCl и перенесении в среду с 3,0 м NaCl и наоборот, а также выявлении устойчивости клеток к острому облучению различными дозами УФ-С света.

\section{Материалы и метолы исслеАования}

Объектом исследования служила клетки Dunaliellasalina IPPAS D- 294, выделенные из соленных озер Апшерона и введенная в культуру. Культуру водорослей выращивали на установке типа «УВКВ» (установка для выращивания культур микроводорослей). Водо- росли выращивали при $27^{0} \mathrm{C}$ в 1-литровыхцилиндрах, наполовину заполненных средой следующего состава (г/л): $\mathrm{KNO}_{3}-5,0 ; \mathrm{KH}_{2} \mathrm{PO}_{4}-1,25 ; \quad \mathrm{MgSO}_{4}-50 ; \mathrm{FeSO}_{4}-0,009$; ЭДТА, раствор микроэлементов в количества 1 мл/л. Среда кроме того содержала 1,5 M и 3MNaCl.Культуры непрерывно продували смесью воздуха с 1,5\% О 2 и освещали белым светом люминесцентных ламп (24вт/м²) 24 часа в сутки.

Темп роста культуры определяли периодическим подсчетом числа клеток в камере Горяева под микроскопом и нефелометрические, измерением оптической плотности суспензии клеток на фотоэлектроколориметре КФК-2. Фотосинтетическую активность клеток измеряли на полярографической установке с применением платинового электрода Кларка, освещая суспензию в термостатированной ячейке белым светом насыщающей интенсивности 100 вт/м².

Регистрацию индукционных кривых замедленной флуоресценций (3Ф) в миллисекундной диапазоне проводили наквантометрической установке с фосфороскопом. В работе даны результаты быстрых и медленных компонент индукционных кривых замедленной флуоресценции и рассчитаны амплитуды индукционного максимума $3 Ф\left(\mathrm{~A}_{m}\right)$, стационарного уровня $3 Ф\left(\mathrm{I}_{\mathrm{cm}}\right)$ и параметра $\left(\mathrm{A}_{m} / \mathrm{I}_{c m}\right)$ клеток галофильной зеленой микроводоросли Dunaliellasalina.

Получение модифицированных клеток Dunaliella и ихоблучение УФсветом

В работе были использованы также модифицированные клетки Dunaliella после гипер- и гипоосмотического солевого шока. Клетки, выращенные в среде с 1,5 $\mathrm{MNaCl}$, осаждали центрифугированием и суспендировали в среде с $3 \mathrm{M} \mathrm{NaCl}(1,5 \rightarrow 3 \mathrm{M}$, гиперосмотический солевой шок) и наоборот, выращенные в $3 \mathrm{MNaCl}$ суспендировали в $1,5 \mathrm{M} \mathrm{NaCl}(3 \rightarrow 1,5 \mathrm{M}$, гипоосмотический солевой шок). После гипер- и гипоосмотического солевого шока и 90 минутной инку бации [1] в темноте (необходимое и достаточное время для частичного вос ста новления функции клеток) измеряли скорость выделения кислорода модифи цированных контрольных и облученных непосредственно прямыми УФ-С лучами клеток.

Для этого по 25 мл суспензии брали для каждой дозы УФ-С облучения, переносили в термостатированную кварцевую емкость, которая обхватывает поверхность УФ лампы (БУВ- 30). Толщина слоя суспензии в кварцевой ем кости для облучения составляла 3 мм, а расстояние между поверхностью сус пензии и лампой 5 мм. Облучение проводили в затемненном боксе $(7,10,11)$. Облученная суспензия переносилась в термостатированную ячейку полярографической уста новки, где измеряли 


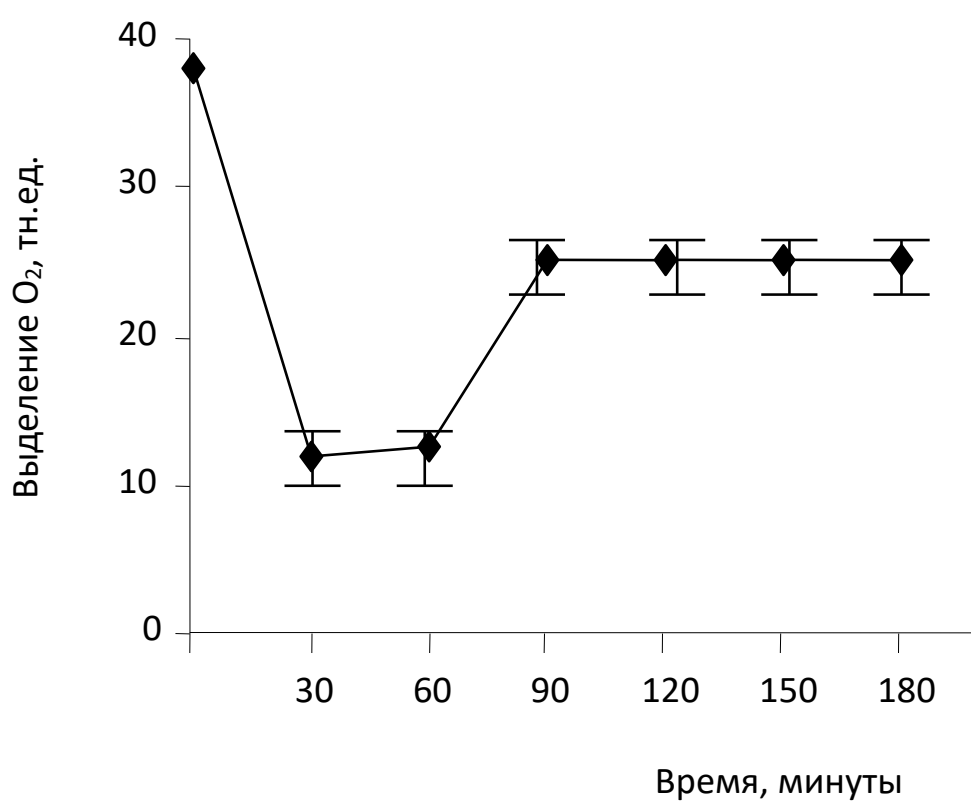

Рис. 1. Зависимость скорости выделения кислорода клетками DunaliellasalinalPPASD-294 при гипоосмотическом солевом шоке от времени инкубации в темноте. Температура $40^{\circ} \mathrm{C}$, интенсивность света 100 вт/м²

скорость выделения кислорода. Контролем служили необлученные модифицированные клетки.

\section{Результаты и обсужление}

По полученным нами ранее данным клетки DunaliellasalinaIPPASD-294 могут выдерживать резкие концентрационные сдвиги $\mathrm{NaCl}$ в обоих направлениях $(1 \mathrm{M} \Leftrightarrow 5 \mathrm{M})$ и размножаться в широких пределах концентраций $(0,5-5 \mathrm{M}) \mathrm{NaCl}$ в среде $(2,3)$.

Также известно, что при гиперосмотическом солевом шоке (повышение в среде концентраций $\mathrm{NaCl}$ и соответственно наружного осмотического давления) в клетках Dunaliella стимулируются процессы, направленные на биосинтез глицерина, выполняющего осморегуляторную и протекторную функции, а при гипоосмотическом солевом шоке (понижение в среде концентраций $\mathrm{NaCl}$ и наружного осмотического давления) снижение концентраций глицерина в цитоплазме[9]. Резкие перепады наружного осмотического давления вызывают соответствующие изменения в цитоплазме в связи с гидратацией и дегидратацией последней, а это в свою очередь может сказываться на фотосинтетической активности клеток.

На рисунке 1 представлены зависимость фотосинтетической активности клеток Dunaliella при гиперосмотическом солевом шоке от времени инкубации в темноте. Как видно из рисунка при гиперосмотическом солевом шоке впервые 30 минут, фотосинтетическая активность клеток резко падает до 30-35\%. В интервале 30-60 минут, фотосинтетическая активность клеток остается в пределах 35-40\%. Начиная с 60 минут и выше в отобранных пробах наблюдается процесс восстановления фотосинтетической активности клеток, которая заканчивается через 30 минут. Последующая инкубация 90-180 минут сохраняет уровень фотосинтетической активности модифицированных клеток на уровне 68-70\% от контроля. Динамику фотосинтетической активности клеток.

Dunaliella при гиперосмотическом солевом шоке от времени инкубации в темноте можно разделить на четыре фазы. Первая фаза, быстрая до 30 минут, связанная с дегидратацией клеток, проникновения ионов внутрь, увеличения внутриклеточного осмотического давления и которая показывает на сколько глубоко подвергается

Фотосинтетическая активность клеток гиперосмотическому солевому шоку. Глубина подавления фотосинтетической активности быстрой фазы зависит от состояния и активности первоначально выращенных клеток. Вторая фаза, 30-60 минут, в основном вероятно, связанная с биосинтезом глицерина, который необходим для увеличения внутриклеточного осмотического давления в ответ на гиперосмотический солевой шок.

Эта фаза проявляется на кривой фотосинтетической активности клеток как нижний стационарный уровень. 


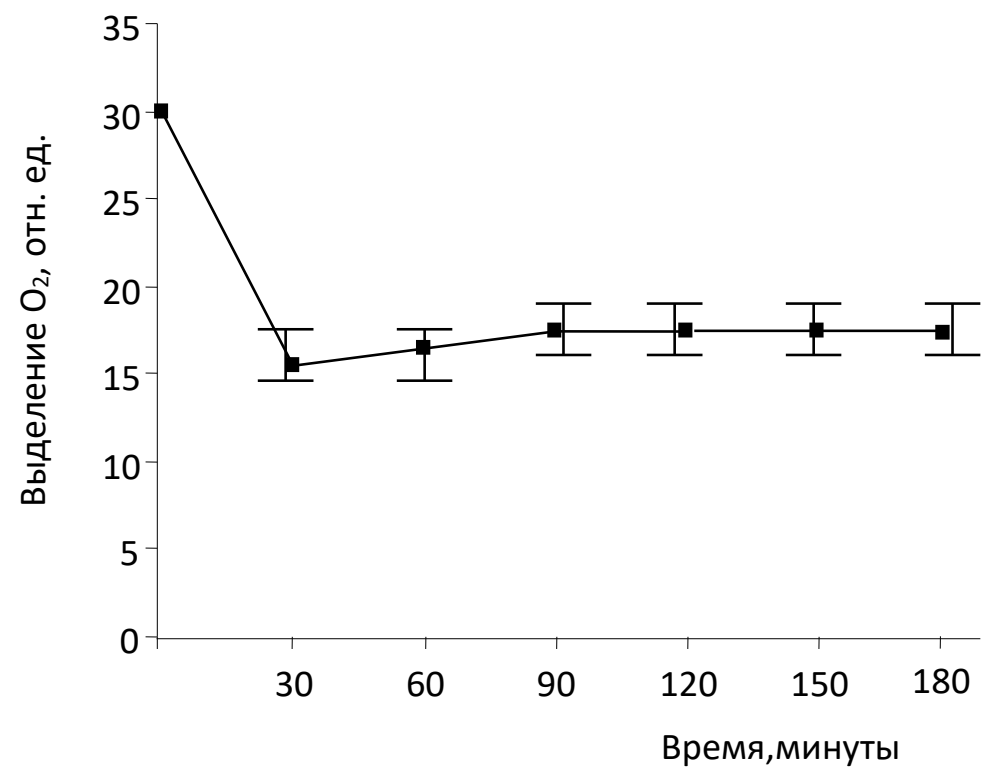

Рис. 2. Зависимость фотосинтетической активности клеток DunaliellasalinalPPASD-294 от времени инкубации в темноте, после гипоосмотического солевого шока. Температура $40^{\circ} \mathrm{C}$, интенсивность света $100 \mathrm{BT} / \mathrm{M}^{2}$

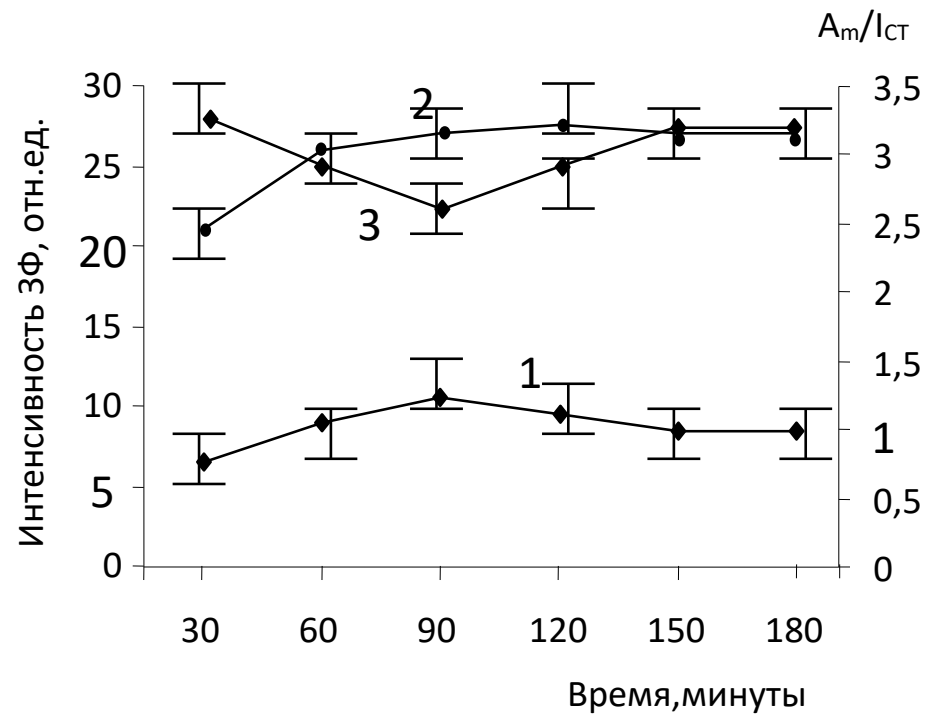

Рис. 3. Изменение параметров (ЗФ), от времени инкубации в темноте, клеток DunaliellasalinalPPASD-294 после гиперосмотического солевого шока.

1 - стационарный уровень $3 Ф\left(\mathrm{I}_{\mathrm{cT}}\right)$;

2 - амплитуда индукционного максимума $3 Ф\left(\mathrm{~A}_{\mathrm{m}}\right)$;

3 - показатель энергизации фотосинтетических мембран $\left(\mathrm{A}_{\mathrm{m}} / \mathrm{I}_{\mathrm{cT}}\right)$

Третья фаза, 60-90 минут по мере накопления глицерина, поглощенные в быстрой фазе, ионы транспортируются обратно в наружную среду, и мы наблюдаем рост фотосинтетической активности модифицированных клеток. Четвертая фаза, 90-180 минут, верхний стационарный уровень фотосинтетической активности, которая на наш взгляд является фазой стабилизации адаптивных реакций модифицированных клеток на гиперосмотический солевой шок.

На рисунке 2 представлены результаты фотосинтетической активности клеток Dunaliella при гипоосмотиче- 


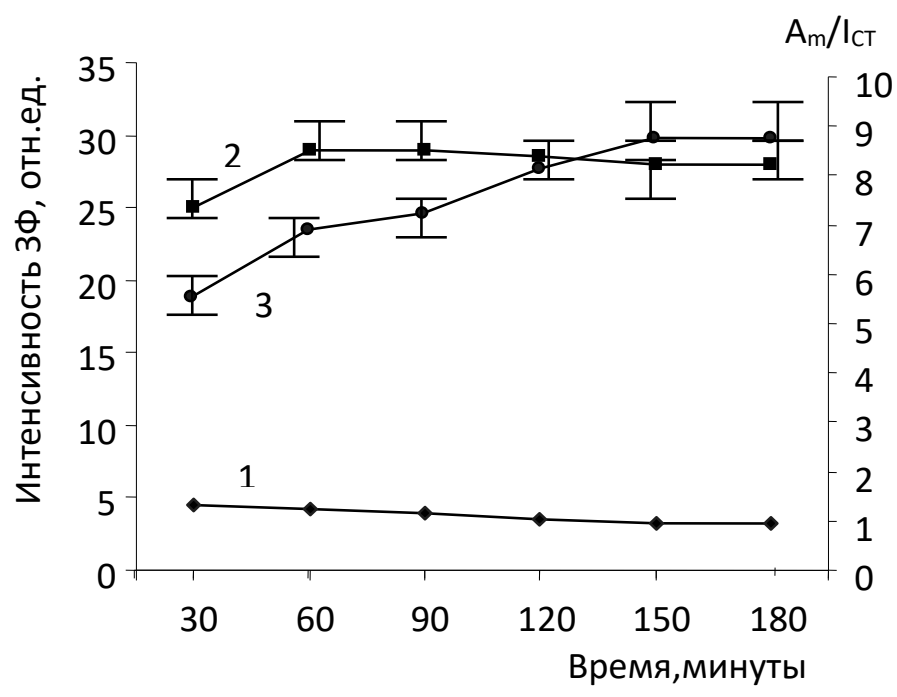

Рис. 4. Изменение параметров замедленной флуоресценции (3Ф), от времени инкубации в темноте, клеток DunaliellasalinalPPASD-294 после гипоосмотического солевого шока.

1 - стационарный уровень 3Ф (I $)_{\text {Tт }}$;

2 - амплитуда индукционного максимума 3Ф ( $\left.\mathrm{A}_{\mathrm{m}}\right)$;

3 - показатель энергизации фотосинтетических мембран $\left(\mathrm{A}_{\mathrm{m}} / \mathrm{I}_{\mathrm{cT}}\right)$.

ском солевом шоке. Как видно из рисунка, на кривой зависимости фотосинтетическая активность первой фазы (до 30 минут, связанная с гидратацией клеток и выходом ионов наружу) претерпевает менее глубокому спаду 50-55\% от контроля. Стационарный уровень фотосинтетической активности клеток устанавливается, в третьей фазе 60-90 минут по мере деградации глицерина. Следует отметить, что фотосинтетическая активность модифицированных клеток после гипоосмотического солевого шока была на уровне 58-60\% от контрольных. Сравнение стационарных уровней при гипер- и гипоосмотическом солевом шоке показали, что в первом случае фотосинтетическая активность после глубокого спада (30-35\%) устанавливается на уровне 68-70\%, а во втором при менее глубоком спаде 50-55\% устанавливается на сравнительно низком стационарном уровне 58-60\% модифицированных клеток. Несмотря на это, время 60 минут инкубации в темноте является необходимым и достаточным для достижения стационарного уровня фотосинтетической активности модифицированных клеток после обоих солевых шоков.

В отличие от характерного изменения фотосинтетической активности клеток, в первые 90 минут инкубации в темноте после гиперосмотического солевого шока, стационарный уровень на кривой замедленной флуоресценции (I) значительно увеличивается, по сравнению с контролем (рис. 3).

Последующие 90 минут инкубации в темноте приводит к незначительному снижению стационарного уров- ня. Как видно из рисунка 4, амплитуда индукционного максимума $\left(A_{m}\right)$ замедленной флуоресценции изменяется практически со стационарным уровнем и после 90 минут инкубации в темноте достигается определенный стационарный уровень индукционного максимума $\mathrm{A}_{\mathrm{m}}$. Параметр, характеризующий относительные изменения индукционного максимума $3 Ф\left(\mathrm{~A}_{\mathrm{m}} / \mathrm{I}_{\mathrm{cT}}\right)$, медленно уменьшается до 70\% в течение 90 минут, затем восстанавливается до определенного уровня, что указывает на снижение и дальнейший рост энергизации фотосинтетических мембран.

Иная картина наблюдается при гипоосмотическом солевом шоке, так стационарный уровень замедленной

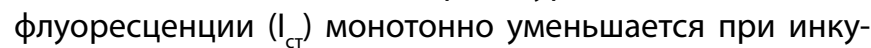
бации в темноте (рис. 4) Амплитуда индукционного максимума $A_{m}$ при этом резко уменьшается в первые 30 минут, по сравнению с контрольными клетками, но по мере увеличения времени инкубации в темноте наблюдается рост с последующим выходом на стационарный уровень. В условиях гипоосмотического солевого шока параметр $\mathrm{A}_{\mathrm{m}} / \mathrm{I}_{\text {ст }}$ уменьшаясь в первые 30 минут не только восстанавливаются, но и превышает на $40 \%$ контрольные клетки. Поскольку усиление энергизации фотосинтетических мембран $A_{m} / I_{\text {ст }}$ происходит на фоне уменьшения нециклического потока электронов в электрон-транспортной цепи (фотосинтетическая активность модифицированных клеток была ниже контрольных), то оно может быть связано с замедлением потребления АТФ в результате торможения темновых процессов фотосинтеза. 


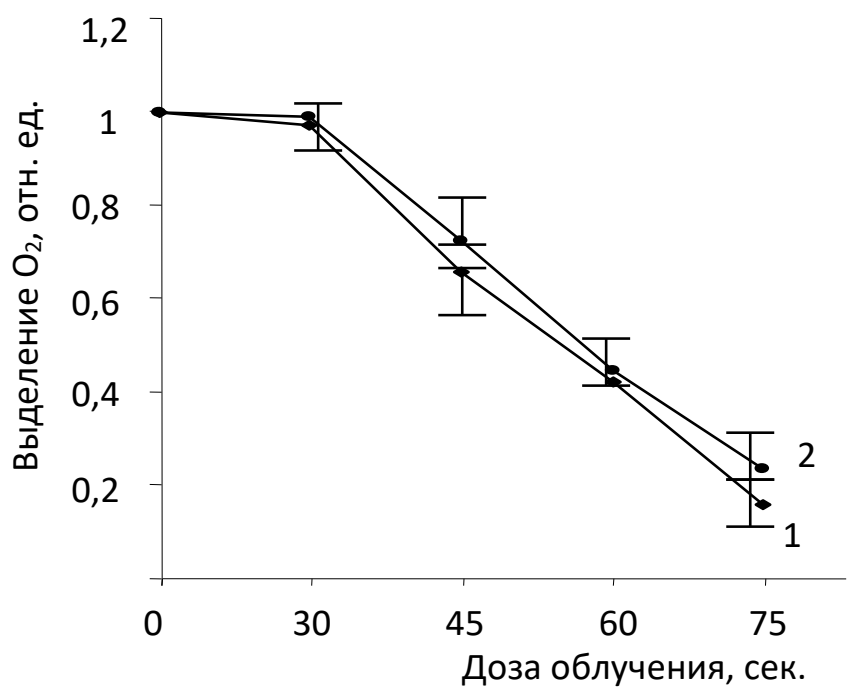

Рис. 5. Зависимость фотосинтетической активности клеток DunaliellasalinalPPASD-294 от дозы УФ-С облучения.

1 - выращенных в 1,5 M NaCl

2 - выращенных в 3,0 $\mathrm{M} \mathrm{NaCl}$

3 - Температура 400С, интенсивность света 100 вт/м².

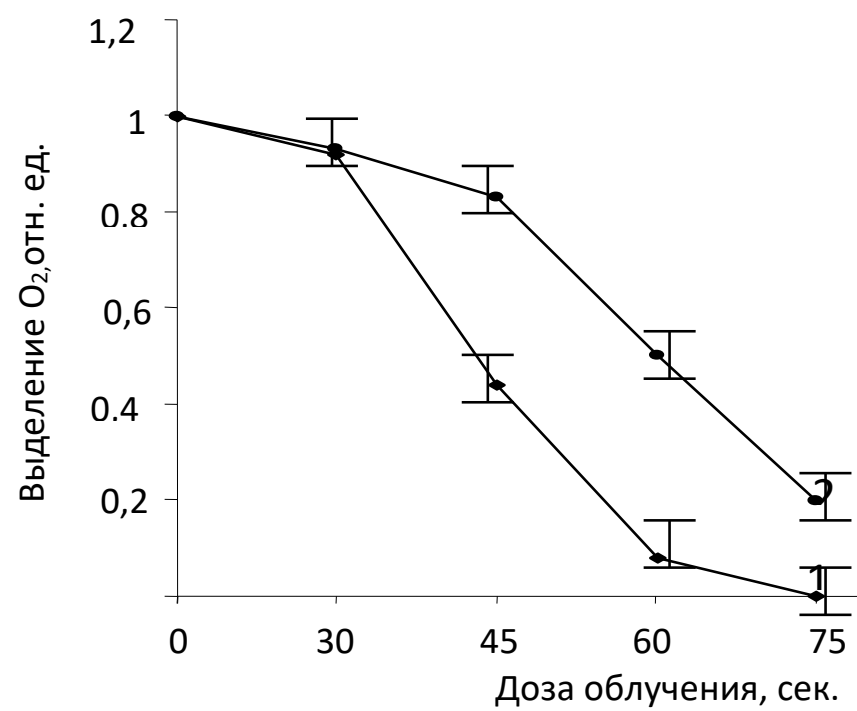

Рис. 6. Зависимость фотосинтетической активности модифицированных после гиперосмотического (1) и гипоосмотического (2) солевого шока, клеток DunaliellasalinalPPASD-294 от дозы УФ-С облучения.

Таким образом, при гипер- и гипоосмотическом солевом шоке происходит изменение световых реакций фотосинтеза в клетках Dunaliella, в частности изменяется скорость транспорта электронов на акцепторной части фотосистемы II, усиливается энергизациятилакоидных мембран и ингибирование фотосинтеза. Инкубирование клеток в темноте позволяет выявить время (90 минут), при котором частично восстанавливаются первичные реакции фотосинтеза, являющиеся частью и кусковым механизмом всей разветвленной системы метаболизма фотосинтезирующих организмов.

Увеличение концентрации хлористого натрия в среде при интенсивно-накопительном режиме культивирования в клетках Dunaliella повышается содержание глицерина и каротиноидов $[3,8]$. Это приводит к умень- 
шению соотношения хлорофиллы/каротиноиды и в конечном счете, снижению фотосинтетической активности клеток [2]. Несмотря на снижение фотосинтетической активности и скорости роста культуры, повышается устойчивость клеток к УФ-С излучению (рис. 5).

На рисунке 5 представлены кривые зависимости фотосинтетической активности клеток, выращенных в среде с 1,5 M (кривая 1) и 3 M (кривая 2) хлористого натрия и с последующим облучением различными дозами УФ-С излучения $[10,11]$. Как видно из рисунка, устойчивость клеток УФ-С излучению заметно отличаются друг от друга. Так при малых дозах (30 сек) фотосинтетическое выделение кислорода клетками (кривая 2) не подвергается существенному изменению.

Иная картина с клетками, выращенными в среде с 1,5 M NaCl, малые дозы заметно подавляют фотосинтетическое выделение кислорода (кривая 1). По мере увеличения дозы функции клеток подавляются и при дозах (60 сек) на кривых снова наблюдается граница устойчивости. Разная резистентность к УФ-С излучению на наш взгляд, вероятно, связано с количеством синтезированных каротиноидов и глицерина клетками, в ответ на повышение концентрации хлористого натрия. Это можно объяснить следующим предположениями: а) наблюдаемый эффект обусловлен участием каротиноидов клетки, определяющих их устойчивость; б) участие в метаболических процессах клетки глицерина, который выполняет осморегуляторные и протекторные функции. Для исключения возможного вклада глицерина были использованы модифицированные клетки, полученные после гипер- и гипоосмотического солевого шока.

Клетки Dunaliella синтезируют (60-90 минут) глицерин (после гиперосмотического солевого шока 1,5 $\rightarrow 3 \mathrm{M}$ ) или теряют его (после гипоосмотического соле- вого шока $3 \mathrm{M} \rightarrow 1,5 \mathrm{M})$. Пигментный состав модифицированных клеток после гиперосмотического солевого шока остаются неизменными и идентичны клеткам, выращенным в среде с 1,5 M NaCl, и пигментный состав модифицированных клеток после гипоосмотического солевого шока соответствует выращенным в среде с 3 $\mathrm{M} \mathrm{NaCl}$.

На рисунке 6 представлены дозовые зависимости действия УФ-С излучения на фотосинтетическую активность модифицированных клеток. Как видно из рисунка, устойчивость модифицированных клеток при малых дозах УФ-С излучения в обоих случаях снизилась, но корреляция между кривыми 1 и 2 с увеличением дозы сохранилась. Модифицированные клетки $3 \mathrm{M} \rightarrow 1,5$ М) оказались и в данном случае устойчивее, чем модифицированные клетки (1,5 M 3 М). Полученные данные говорят о том, что внутриклеточный и вновь синтезированный глицерин в клетках не проявляют протекторные функции по отношению к УФ-С лучам.

Влияние экстремальных температур на фотосинтетическую активность модифицированных клеток показали, что синтезированный глицерин после гиперосмотического солевого шока, смещает температурный максимум фотосинтетического выделения кислорода с 400С до 42,50С, это дает нам основание считать, что глицерин в клетках Dunaliella выполняет роль протектора, при экстремально повышенных температурах.

Таким образом, полученные данные свидетельствуют о том, что повышение концентрации хлористого натрия в среде выращивания, стимулируют биосинтез каротиноидов, которые проявляют повышенную резистентность клеток DunaliellasalinaIPPASD-294 к УФ-С излучению, а глицерин кроме основной осморегулярной функции, выполняет также роль протектора в экстремально повышенных температурах.

\section{ЛИТЕРАТУРА}

1. Ализаде Г.И., Абдуллаев Х. Д., Наджафов М. Г. Ответные реакции клеток галофильной водоросли DunaliellasalinalPPASD-294 на гипер- и гипоосмотический солевой шок. //Вестник Бакинского Университета, № 2, 2002, стр. 71-77

2. Наджафли М. Г. Влияние солености среды на рост, пигментный состав и функциональную активность клетокDunaliella salına.// Hayчно- технический и производственный журнал, Экология и водное хозяйство. № 5, декабрь, 2011, стр.18-22.

3. Масюк Н. П. Морфология, систематика, экология, географическое распространение рода Dunaliellasalina. //Наумова думка, Киев, 1973, стр. 242

4. Масюк Н.П., Посудин Ю. И., Лилицкая Г. Г. Фотодвижение клеток DunaliellaTeod. (Dunaliellales, Chlorophyceae, Viridiplantae). — Киев, 2007.— 264 с.

5. Карнаухов В. Н. Функции каротиноидов — объект биофизических исследований. //Биофизика, 2000, том 45, вып. 1. с. 364-384.

6. Курочкина В.А.Внутрипопуляционная изменчивость функциональных и морфологических параметров водорослей Сonticribraweissflogiiи Attheyaussurensisпри осмотическом стрессе.Дисс. на соиск. Уч. Степ. Кандид. Биол. Наук. Москва, МГУ- 2019. 135 с.

7. Ладыгин В.Г., Ширшикова Г. Н. Влияние состава каротинов на устойчивость клеток водорослей к действию УФ-С излучению. //Физиология растений, т. 40, № 4, 1993, стр. 644-649

8. Ларсен Х. Биохимические факторы влияющие на галотолерантность у Dunaliella. //Сб. научных трудов «Фототрофные микроорганизмы», Пущино, 1988, стр. 28-35 
9. Najafli M.H., A. G. Gadimov, Z. I. Abbasova, S. M. Rasulova and Gani-zade, S.I. 2019. Effect of Low Positive Temperature and Salinity on the Catalase Ferments Activity and Proliferation of Dunaliella Salina Ippas D-294 Cells. Int.J.Curr.Res.Aca.Rev. 7(7), 45-50.

10. Hollosy F. Effect of ultraviolet radiation on plant cells. //J.Micron 33, 2002, pp. 179-197

11. Kovacs E, Keresztes A. Effect of gamma and UV-B/C radiation on plant cells. //J. Micron 33, 2002, pp. 199-210

( ) Наджафли Махаббат Гумбат оглы (Mohobbatnecefli@gmail.com ),

Гадимов Аладдин Гасан оглы ( agadimov@mail.ru ), Расулова Садагат Мирбаба гызы ( Sadaqat65@mail.ru ).

Журнал «Современная наука: актуальные проблемы теории и практики»

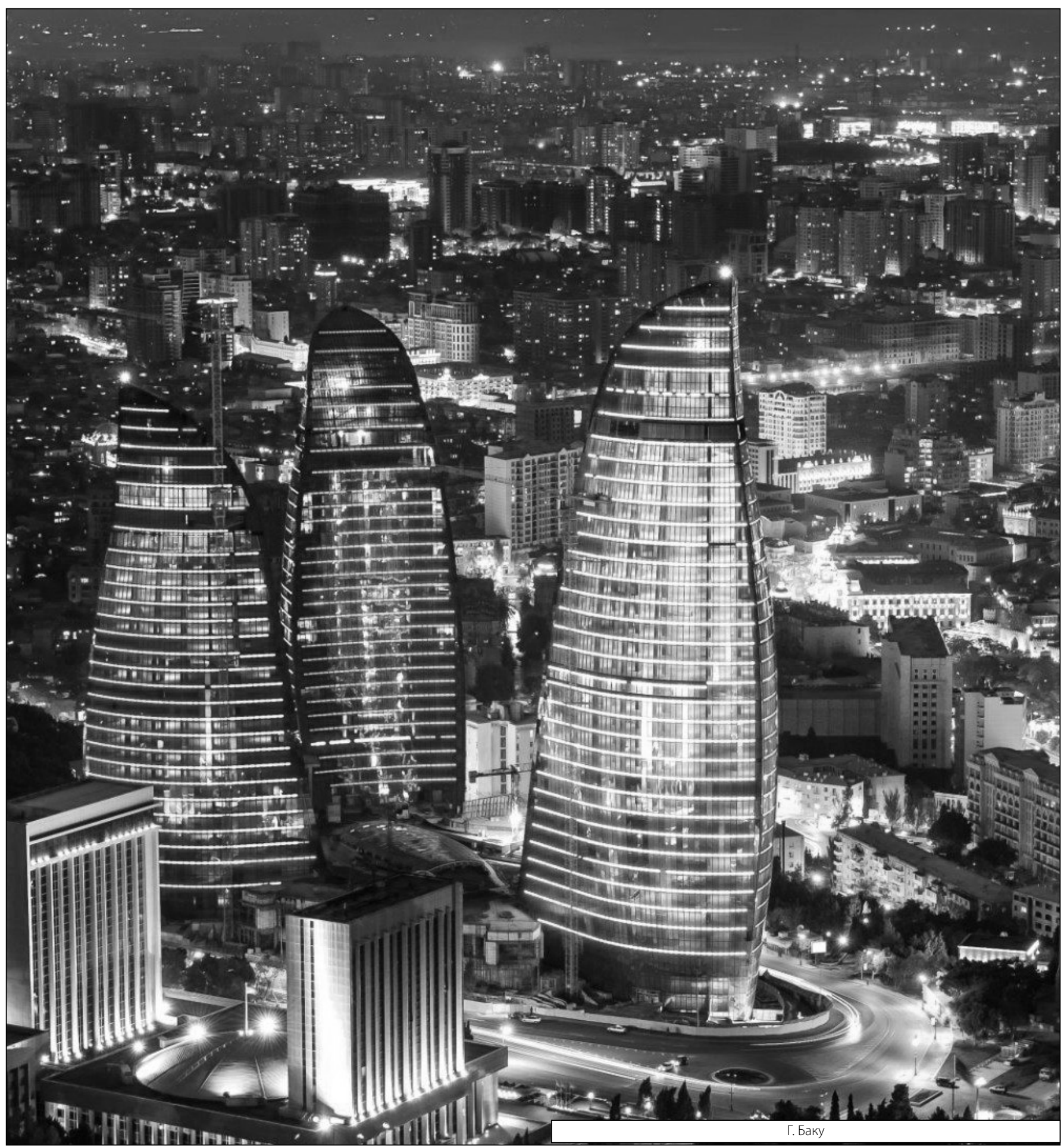

